\title{
Selinexor reduces the expression of DNA damage repair proteins and sensitizes cancer cells to DNA damaging agents
}

\author{
Trinayan Kashyap ${ }^{1}$, Christian Argueta ${ }^{1}$, Thaddeus Unger $^{1}$, Boris Klebanov ${ }^{1}$, Sophia \\ Debler $^{1}$, William Senapedis ${ }^{1}$, Marsha L. Crochiere ${ }^{1}$, Margaret S. Lee ${ }^{1}$, Michael \\ Kauffman $^{1}$, Sharon Shacham ${ }^{1}$ and Yosef Landesman ${ }^{1}$ \\ ${ }^{1}$ Karyopharm Therapeutics Inc., Newton, MA 02459, USA \\ Correspondence to: Trinayan Kashyap, email: tkashyap@karyopharm.com
}

Keywords: DNA damage repair; selinexor; nuclear export; chemotherapy

Received: March 21, $2018 \quad$ Accepted: June 01, $2018 \quad$ Published: July 20, 2018

Copyright: Kashyap et al. This is an open-access article distributed under the terms of the Creative Commons Attribution License 3.0 (CC BY 3.0), which permits unrestricted use, distribution, and reproduction in any medium, provided the original author and source are credited.

\section{ABSTRACT}

Introduction: The goal of this study was to examine the effects of selinexor, an inhibitor of exportin-1 mediated nuclear export, on DNA damage repair and to evaluate the cytotoxic effects of selinexor in combination with DNA damaging agents (DDAs) in cancer cells.

Results: Selinexor reduced the expression of DNA damage repair (DDR) proteins. This did not induce significant DNA damage in tested cell lines. Inhibition of DDR protein expression resulted in enhanced cancer cell death when cells were pretreated with DDAs. In contrast, enhanced cell death was not detected in cells that were pretreated with selinexor then with DDAs. In vivo, single-agent selinexor, docetaxel, or cisplatin treatment resulted in $66.7 \%, 51.5 \%$, and $26.6 \%$ tumor growth inhibition (TGI), respectively, in an MDA-MB-231 xenograft model. Consequently, combination treatment with docetaxel or cisplatin followed by selinexor in vivo resulted in $\mathbf{9 3 . 9 \%}$ and $103.4 \%$ TGI, respectively. Immunohistochemical staining and immunoblot analysis of tumor sections confirmed reduced expression of DDR proteins.

Conclusion: Selinexor treatment inhibited DDR mechanisms in cancer cell lines and therefore potentiated DNA damage-based therapy. The sequential combination of DDAs followed by selinexor increased cancer cell death. This combination is superior to each individual therapy and has a mechanistic rationale as a novel anticancer strategy.

Methods: Cancer cells treated with selinexor \pm DDAs were analyzed using reverse phase protein arrays, immunoblots, quantitative PCR and immunofluorescence. Mice bearing MDA-MB-231 tumors were treated with subtherapeutic doses of selinexor, cisplatin, docetaxel and selinexor in combination with either cisplatin or docetaxel. Tumor growth was evaluated for 25 days.

\section{INTRODUCTION}

The export of large macromolecules from the nucleus to the cytoplasm is a highly dynamic and tightly regulated process. Exportin-1 (XPO1, also known as chromosome region maintenance 1 or CRM1) is the best characterized member of the karyopherin family of nuclear transport proteins and is responsible for the export of numerous cargos, including tumor suppressor proteins (TSPs) and regulators of cell growth [1]. Elevated expression of XPO1 mRNA and/or protein has been observed in many types of cancer, and high levels of XPO1 expression are associated with poor prognosis in cancer patients [2-5]. To harness the therapeutic potential of this target, a new class of small molecule inhibitors of XPO1-mediated nuclear export was recently developed, named Selective Inhibitor of Nuclear Export (SINE) compounds.

The lead SINE compound is the orally bioavailable drug selinexor (KPT-330), which is currently under evaluation in phase 2 and 3 clinical trials. Selinexor has demonstrated promising antitumor activity in both solid and hematological cancer types [6-8]. Selinexor and other 
SINE compounds form slowly reversible covalent bonds with cysteine-528 of the cargo-binding pocket of XPO1. As a result, XPO1 is unable to interact with and export cargo proteins [9], including the TSPs p53, p21, p27, APC, pRb, FOXOs, and the eukaryotic translation initiation factor eIF4E, which facilitates export and translation of protooncogenes such as c-Myc, Bcl-2, Bcl-6, cyclins and HSP70. Ultimately, the nuclear enrichment or sequestering of these cargo proteins leads to a reduction of oncogenic translation and the activation of cell cycle arrest, thereby initiating cancer cell death [9].

In healthy cells, cell cycle arrest is needed to control normal tissue growth and to protect the integrity of cellular DNA from mutational assaults, such as free radicals from cellular metabolism, environmental toxins, or cancer treatments, including radiation and chemotherapy [10]. Once DNA damage is detected by a cellular surveillance mechanism, DNA damage response and cell cycle checkpoint proteins induce growth arrest and allow for repair [10]. The repair is executed by nonredundant proteins in a highly coordinated and complimentary manner through five major repair pathways: (1) direct reversal, (2) nucleotide excision repair (NER), (3) base excision repair (BER), (4) mismatch repair (MMR), and (5) recombination repair. However, if the damage cannot be completely repaired, the cell undergoes senescence or apoptosis [11]. Many cancer therapies, including chemo- and radiotherapy, exert their cytotoxic effects by inducing DNA damage [12]. In fact, the extent of DNA damage directly affects the overall cellular response to commonly used cancer therapies [13]. Furthermore, inhibition of different DDR pathways can enhance sensitivity of cancer cells to therapy and increase the level of DNA damage, resulting in synthetic lethality [14]. To this end, several inhibitors of DDR are currently under evaluation in preclinical studies and clinical trials for their ability to enhance DNA damage-induced tumor cell death [14].

In this study, we show that selinexor significantly reduces the expression of DNA damage repair proteins, prevents recovery from DNA damage, and synergizes with DNA damage -inducing chemotherapies to stimulate cell death and reduce tumor size. In addition, the extent of repair protein repression by selinexor correlates with overall sensitivity of cancer cells to the drug. These data suggest that combining selinexor with DNA damage agents (DDA) is a promising strategy for cancer treatment and supports further clinical optimization of dose and schedule to achieve the best therapeutic advantage from the combination treatment of selinexor with DDA.

\section{RESULTS}

\section{Selinexor reduces the expression of DNA damage repair proteins}

The selinexor-sensitive fibrosarcoma cell line, HT$1080\left(\mathrm{IC}_{50}-100 \mathrm{nM}\right)$ and the resistant alveolar soft part sarcoma (ASPS) cell line ASPS-KY $\left(\mathrm{IC}_{50}>10 \mu \mathrm{M}\right)$ were treated with selinexor at $1 \mu \mathrm{M}$ for 24 hours or $10 \mu \mathrm{M}$ for 48 hours. Next, protein expression levels were quantified from whole cell lysates by reverse phase protein array (RPPA) both before and after treatment. RPPA is an antibody-based functional proteomic analysis for both tumor tissue and cultured cells [15]. Ingenuity pathway analysis (IPA) of 150 proteins revealed a reduction in the expression of 8 proteins with roles in DDR: CHEK1, Rad51, MLH1, MSH2, MSH6, PMS2, FOXM1, and Chk2 (Figure 1A; red stars) [16]. The reduction in protein levels was confirmed by western blot analysis using antibodies against the same set of DDR proteins (Figure 1B).

\section{Selinexor treatment reduces $\mathrm{mRNA}$ and protein levels of DDR gene products in solid and hematological cancer cell lines}

To confirm that regulation of DDR protein expression by selinexor is not limited to sarcomas, MM.1S (multiple myeloma, selinexor $\mathrm{IC}_{50}=30 \mathrm{nM}$ ) and MDA-MB-231 (triple negative breast cancer, selinexor $\mathrm{IC}_{50}=6.5 \mu \mathrm{M}$ ) cell lines were treated with selinexor for 24 hours, followed by quantitation of mRNA and protein expression by RT-PCR and immunoblotting, respectively. Selinexor reduced the steadystate mRNA levels of key DDR genes in a dose dependent manner: MSH6, MSH2, CHEK1, MLH1 and Rad51, (Figure 2A). Interestingly, while selinexor did not alter the mRNA levels of PMS2 in the two cell lines (Figure 2A), it inhibited PMS2 steady-state protein levels (Figure 2B). These results suggest that selinexor can downregulate the expression of DDR gene products on both the transcriptional and translational level. Selinexor also reduced the protein levels of DDR genes (Figure 2C) in the following cell lines: Toledo (Diffused Large B Cell Lymphoma), selinexor $\mathrm{IC}_{50}=410 \mathrm{nM}$ ), A549 (non-small cell lung cancer, $\mathrm{IC}_{50}=6.5 \mu \mathrm{M}$ ), THP1 (acute monocytic leukemia, $\mathrm{IC}_{50}=3 \mu \mathrm{M}$ ) and MOLM13 (acute myeloid leukemia, $\mathrm{IC}_{50}=190 \mathrm{nM}$ ). We compared the extent of DDR protein reduction with their selinexor sensitivity across these hematological cell lines (Figure 2D). The results suggest that the extent of DDR protein reduction is correlated with overall sensitivity of these cell lines to selinexor $\left(\mathrm{R}^{2}\right.$ between 0.6970 and 0.9875). Analysis of the effects of selinexor on the expression of other DDR genes revealed that treatment also lowered the mRNA steady state levels of other genes, which are responsible for DNA damage surveillance and repair: ATR, CHEK1, ATM, Chk2, BRCA1, BRCA2, RAD51, RAD52, FANCB, PALB2, XRCC1, PARP1, DNA ligase 3, ERCC4, ERCC6 and RPA2 (Supplementary Figure 1).

\section{Reduction in the levels of DDR genes by selinexor is an early pre-apoptotic event}

To evaluate when selinexor exposure effects the DDR pathway, MV-4-11 (leukemia, $\mathrm{IC}_{50}=120 \mathrm{nM}$ ), Figure 3A) and MDA-MB-231 (Figure 3B) cells were treated with 
$200 \mathrm{nM}$ or $1 \mu \mathrm{M}$ selinexor, respectively, and sampled at 2, $4,6,12$, and 24 hours after exposure. Selinexor reduced steady-state protein levels of the DDR genes as early as 2 hours post-exposure while the cytotoxic effects of selinexor, shown by full length (FL) and cleaved (CL) caspase-3, were only evident following prolonged drug exposure of 12 hours or longer. Thus, selinexor interferes with DDR early in the apoptotic pathway.

\section{Selinexor inhibits recovery after treatment with DNA damaging agents}

To further elucidate the mechanism of action of selinexor in the DDR pathway, we tested if selinexor induces DNA damage and/or affects DDR. DNA damage by DDA was measured through detection of the DNA-double-strand-break marker $\gamma$ H2A.X immunofluorescence staining after 2 hours of treatment with doxorubicin in osteosarcoma (U-2 OS) cells (Figure 4). When the cells were allowed a 48-hour recovery post-treatment, $\gamma \mathrm{H} 2 \mathrm{~A} . \mathrm{X}$ staining intensity was reduced. However, a 48-hour recovery of cells in media with a suboptimal dose of selinexor, resulted in a higher $\gamma \mathrm{H} 2 \mathrm{~A}$.X staining than recovery without selinexor. These data suggest that selinexor interferes with the cell's ability to repair DNA damage. Importantly, treatment with selinexor alone did not induce significant DNA damage under the same conditions (Figure 4).

\section{Selinexor exhibits synergistic cytotoxic effects in combination with different DNA damaging agents}

Because selinexor reduced DDR protein levels, we examined if the combination of selinexor with different types of DNA damaging agents would result in synergistic cytotoxicity. In order to assess this hypothesis, selinexor was combined with agents that induce single strand breaks (SSB)such as docetaxel (Figure 5A) and gemcitabine (Figure 5B), or with an agent that induces double strand breaks (DSB) such as cisplatin (Figure 5C). When compared to single-agent treatments, all 3 combinations with selinexor showed increased cell death as measured by cleaved caspase-3. In Figure $5 \mathrm{~A}$ and $5 \mathrm{C}$, reduction of DDR proteins in breast cancer (MDA-MB-231) cells after selinexor treatment is observed in the presence of docetaxel and cisplatin, respectively. Pancreatic cancer (Mia-PaCa2) cells exposed to $5 \mu \mathrm{M}$ gemcitabine for 24 hours showed increased phosphorylation of CHEK1 at serine 317 and 345, which is indicative of CHEK1 activation [17] (Figure 5B). However, treatment with

A

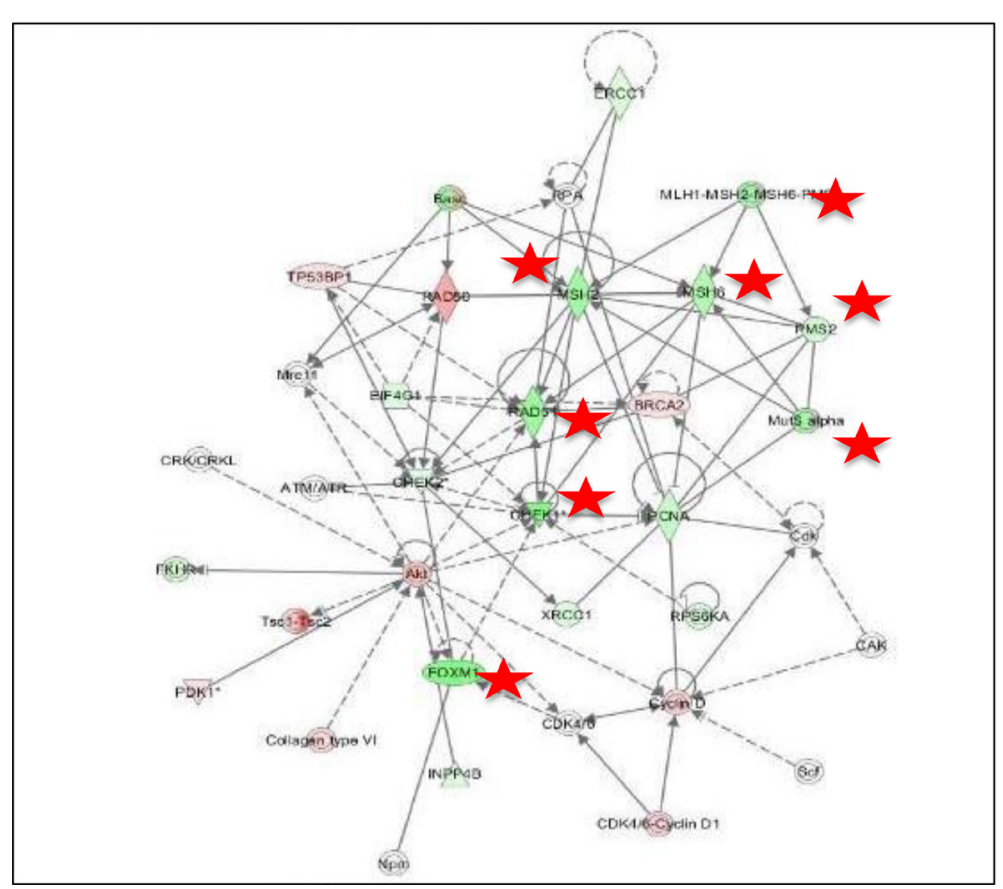

B

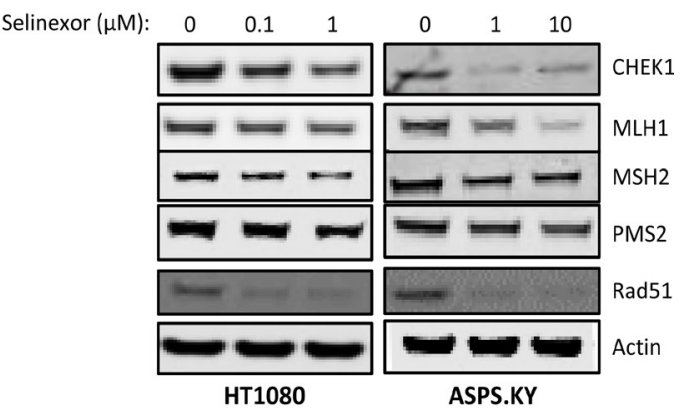

Figure 1: Selinexor reduces the expression of DDR proteins. (A) Ingenuity pathway analysis (IPA) of 150 proteins from cell lysates of sarcoma cell lines ASPS-KY and HT1080 treated with $10 \mu \mathrm{M}$ and $1 \mu \mathrm{M}$, respectively, of selinexor for 24 hours tested by reverse phase protein array (RPPA) revealed reduction in the expression of 8 proteins (red stars) with a role in DDR. Node shapes represent functional classes of protein products; rectangles with solid lines for cytokines, rectangles with dotted lines for growth factors, triangles for phosphatases, concentric circles for groups or complexes, diamonds for enzymes, and ovals for transcriptional regulators or modulators. (B) Western blot of proteins from whole cell lysates of HT1080 cells treated with $0,0.1$, or $1 \mu \mathrm{M}$ selinexor and ASPS-KY cells treated with 0 , 1 , or $10 \mu \mathrm{M}$ selinexor confirmed the RPPA results suggesting down-regulation of CHEK1, MLH1, MSH2, PMS2 and Rad51 protein levels from selinexor treatment in both cell lines. 


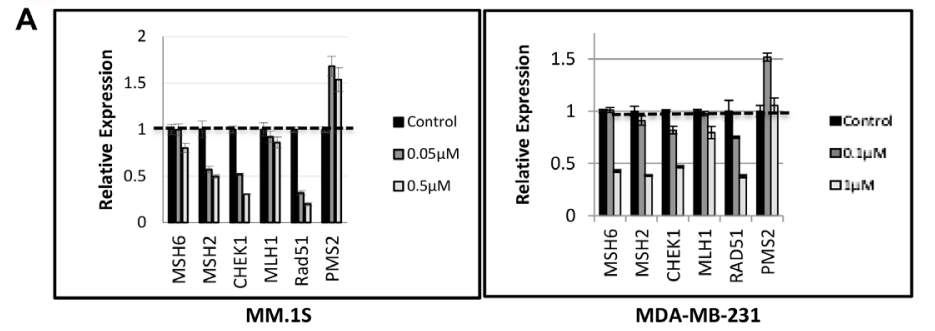

C

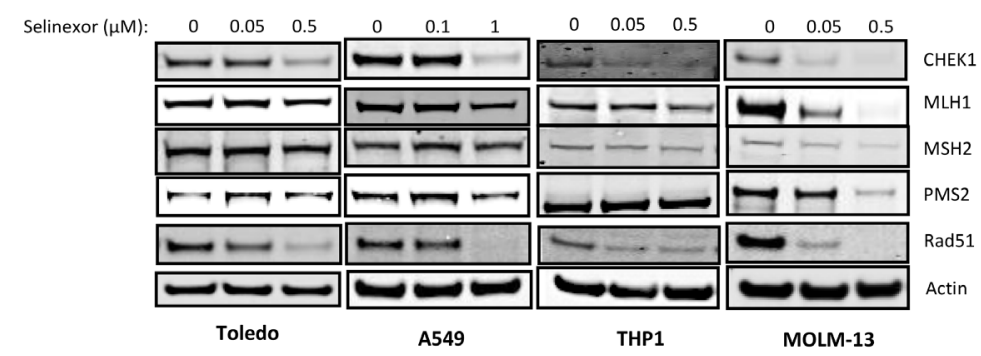

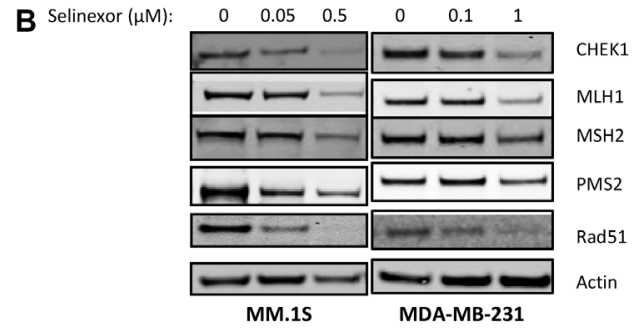

D

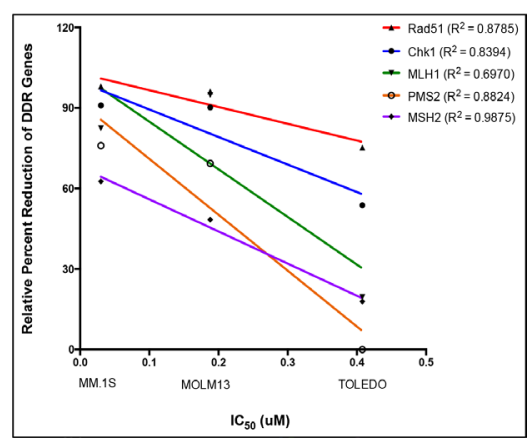

Figure 2: Selinexor suppresses expression of DNA damage gene products at the transcriptional and post-transcriptional levels in both solid and hematological cancer cells. (A) MM.1S cells were treated with 0 (control), 0.05 , or $0.5 \mu \mathrm{M}$ selinexor and MDA-MB-231 cells were treated with $0,0.1$, or $1 \mu \mathrm{M}$ selinexor for 24 hours. Real-time PCR indicated that selinexor reduced the transcript levels of MSH6, MSH2, CHEK1, MLH1 and Rad51 in a dose-dependent manner. (B) Immunoblots of whole cell lysates from MM.1S cells treated with $0,0.05$, or $0.5 \mu \mathrm{M}$ selinexor and MDA-MB-231 treated with $0,0.1$, or $1 \mu \mathrm{M}$ selinexor for 24 hours showed a reduction of the DNA damage repair proteins CHEK1, MLH1, MSH2, PMS2 and Rad51 in a dose-dependent manner. (C) Immunoblots of whole cell lysates from A549 cells treated with $0,0.1$, or $1 \mu \mathrm{M}$ selinexor and Toledo, MOLM-13, and THP-1 cells treated with $0,0.05$, or $0.5 \mu \mathrm{M}$ selinexor for 24 hours also showed a reduction in the expression of CHEK1, MLH1, MSH2, PMS2 and Rad51 (D) The reduction in the levels of DDR proteins is compared for MM.1S, MOLM13 and Toledo. The reduced levels of DDR proteins were found to be directly proportional to the sensitivity of the cells to selinexor.

A 200nM Selinexor

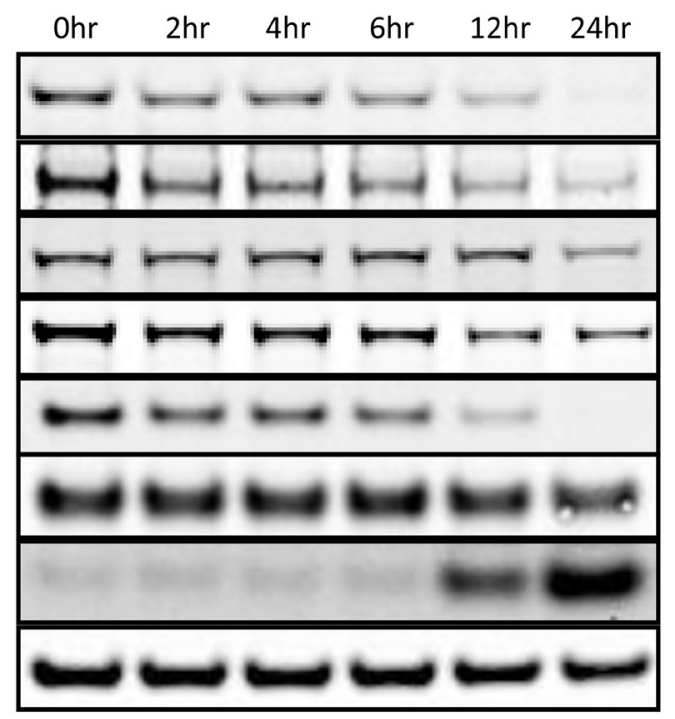

MV-4-11
B

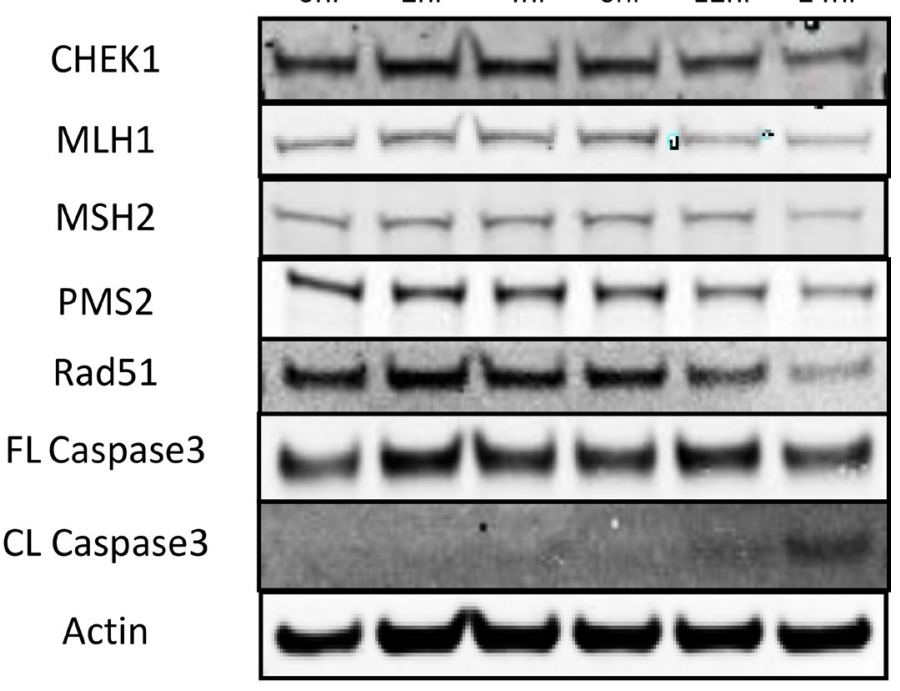

MDA-MB-231

Figure 3: Reduced expression of selinexor dependent expression of DNA damage repair proteins detected prior to cell death. Immunoblots of whole cell lysates from (A) MV-4-11 and (B) MDA-MB-231 cells treated with $200 \mathrm{nM}$ or $1 \mu \mathrm{M}$ selinexor for 2, 4, 6, 12 and 24 hours. Reduction in the levels of the DDR proteins CHEK1, MLH1, MSH2, PMS2 and Rad51 after selinexor treatment is seen before cell death. 
gemcitabine in the presence of $1 \mu \mathrm{M}$ selinexor inhibited this activation (phosphorylation) of CHEK1 through reduction of steady-state CHEK1 protein. Thus, selinexor and DDAs together inhibited DDR and enhanced apoptosis as demonstrated by increased caspase- 3 cleavage.

\section{Selinexor is more cytotoxic to cancer cells when treated after DNA-damaging agents}

In combination therapies, the order of exposure to different drugs can be critical to achieving the best possible outcome. To test if the order of exposure to selinexor and DDAs affected their cytotoxic effect, acute myeloid leukemia cells (MOLM13) were pre-treated with idarubicin for 24 hours followed by 24 hours of selinexor (Figure $6 \mathrm{~A})$. The cells showed more DNA damage, as indicated by increased $\gamma \mathrm{H} 2 \mathrm{~A}$.X levels and cell death (i.e. increased cleaved PARP-1 and caspase- 3 proteins) when compared to 48-hour cotreatment with both compounds or pretreatment with selinexor followed by idarubicin (Figure 6A). A similar result was seen in multiple myeloma (H929) cells treated with doxorubicin then selinexor (Figure 6B). These data support the model where pre-treatment with a DDA followed by exposure to selinexor is more cytotoxic than the reverse sequence or concurrent treatment.

\section{Combination treatment of selinexor with SSB or DSB DNA-damaging agents shows synergistic anticancer effects in breast cancer xenograft models}

To further expand on the in vitro observations, nu/ nu mice engrafted with the breast cancer MDA-MB-231 cells were treated with vehicle, selinexor, cisplatin (DSB agent), docetaxel (SSB agent), or selinexor plus either of the DDAs. The mean tumor volume for the vehicle control group (Group 1) increased from $172 \mathrm{~mm}^{3}$ on day 1 to $665 \mathrm{~mm}^{3}(287 \%)$ on day 25. Mice treated with $2.5 \mathrm{mg} / \mathrm{kg}$ selinexor, $4 \mathrm{mg} / \mathrm{kg}$ cisplatin, and $4 \mathrm{mg} / \mathrm{kg}$ docetaxel alone showed a $68 \%(p<0.05), 28 \%$ (not significant) or $53 \%$ $(p<0.05)$ tumor growth inhibition (TGI), respectively, when compared to vehicle control. Sequential treatment of $4 \mathrm{mg} / \mathrm{kg}$ docetaxel followed by $2.5 \mathrm{mg} / \mathrm{kg}$ selinexor or $4 \mathrm{mg} / \mathrm{kg}$ cisplatin followed by selinexor resulted in 93.9\% $(p<0.001)$ TGI and $103.4 \%(p<0.001)$ TGI $(9.6 \%$ tumor regression), respectively, after 25 days (Figure 7A). Selinexor treatment alone or in combination with DDAs initially resulted in animal weight loss; however, all groups recovered and there were no statistically significant differences in body weight among the treatment groups at the end of the study, as shown in Figure $7 \mathrm{~B}$.

\section{Selinexor inhibits the expression of DDR proteins in vivo}

To evaluate the impact of selinexor on DDR proteins in vivo, the tumors from the vehicle, selinexor, docetaxel, cisplatin, and combination-treated groups were harvested at the end of the study (Figure 7C). Due to the minute size of the tumors from the combination -treated animals, further analysis was not possible. The expression of DDR proteins was examined using immunoblots in tumors from vehicle, selinexor, cisplatin, and docetaxel-treated animals. Selinexor, even at $2.5 \mathrm{mg} / \mathrm{kg}$, lowered DDR protein expression, while cisplatin and docetaxel had no effect on the steady-state levels of the DDR proteins.

\section{DISCUSSION}

Selinexor is a first-in-class, orally bioavailable SINE compound. Selinexor covalently binds to the nuclear export protein XPO1 and inactivates its function. This leads to the nuclear accumulation of key TSPs and the translation initiation factor eIF4E [18]. eIF4E nuclear export is essential for the translation of proto-oncogenes, such as c-Myc, which regulates the transcription of other key DDR genes [19]. DDR is essential for the maintenance of genomic stability and cell survival. Upregulation of

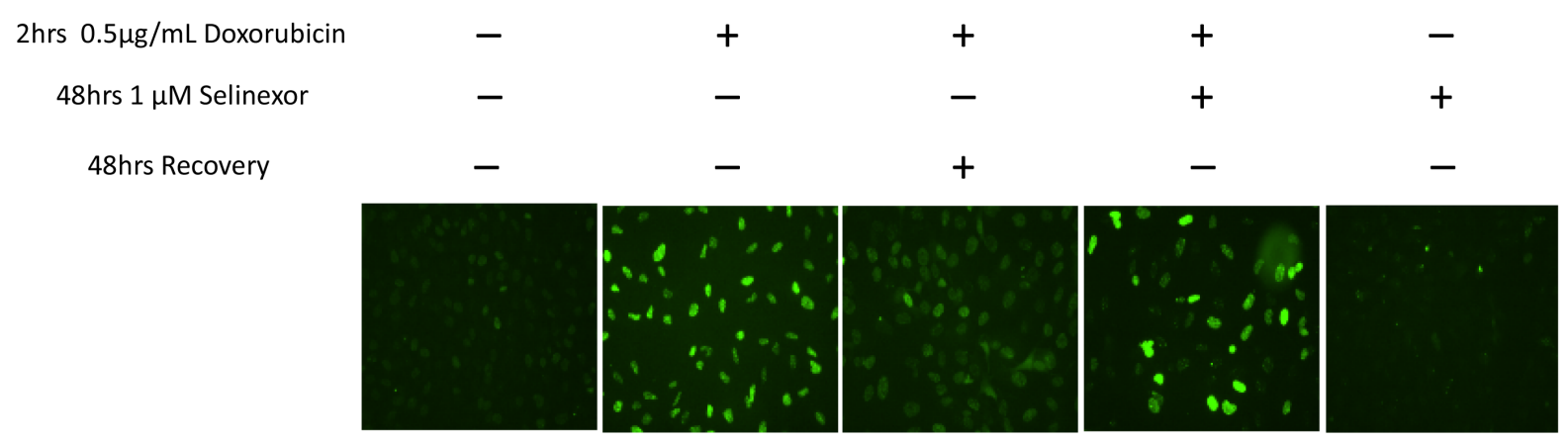

Figure 4: Selinexor blocks recovery from damage caused by DDA. Immunofluorescent detection of $\gamma \mathrm{H} 2 \mathrm{~A} . \mathrm{X}$ in U2-0S cells either untreated or treated for 2 hours with $0.5 \mu \mathrm{g} / \mathrm{mL}$ doxorubicin. The cells were then washed and treated with $100 \mathrm{nM}$ selinexor or vehicle for $48 \mathrm{hrs}$. DNA damage was detected by staining with $\gamma \mathrm{H} 2 \mathrm{~A}$.X. DNA damage due to doxorubicin persisted longer in the presence of selinexor. Selinexor alone did not induce DNA damage. 
several DDR genes, which is observed in several cancers, can increase the efficiency of the DNA repair process and is associated with resistance to chemotherapy and poor prognosis [20]. Consistently, the inhibition of the DDR pathway enhances the therapeutic effects of DNA-damage inducing agents [14].

In vitro and in vivo studies were used in this study to examine the effects of selinexor in combination with several DDAs: cisplatin, gemcitabine, idarubicin, doxorubicin and docetaxel. DDAs induce different types of damage, which activate specific DDR mechanisms to repair the damage (see Table 1). These agents are frequently used to treat a broad range of cancer indications. The results in this study show that the antitumor effects of DNA damage-inducing chemotherapies are enhanced by selinexor. We have previously described a selinexor-mediated reduction of c-Myc protein levels in several cancers: multiple myeloma [25], mantle cell lymphoma [26], chronic lymphocytic leukemia [27], non-small cell lung cancer [28], esophageal squamous cell carcinoma [29], and acute myeloid leukemia (AML) [30]. In AML, we previously demonstrated that binding of c-Myc to Rad51 and CHEK1 promoters is significantly decreased by selinexor treatment, therefore proposing at least one direct mechanism of action by which selinexor can directly reduce expression of DDR genes [30]. Here we show that selinexor reduced the expression of additional DDR
A

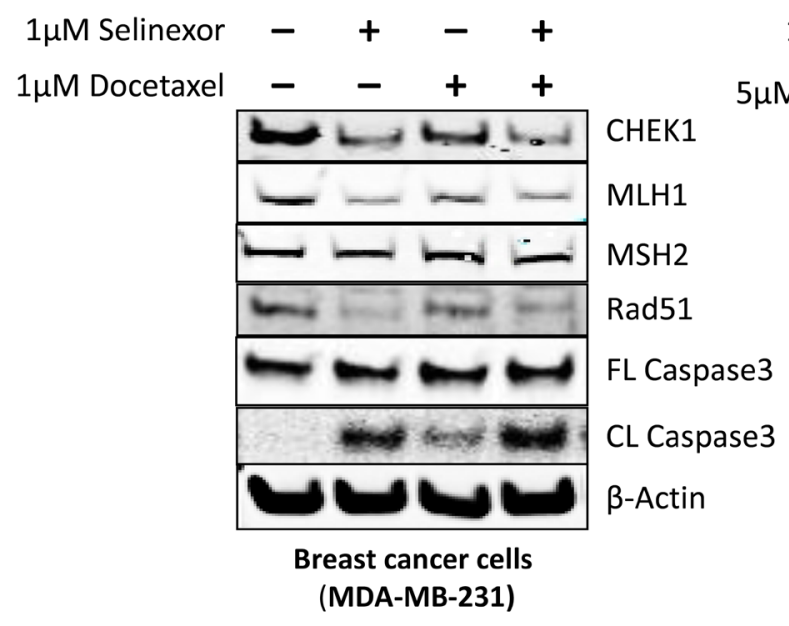

B

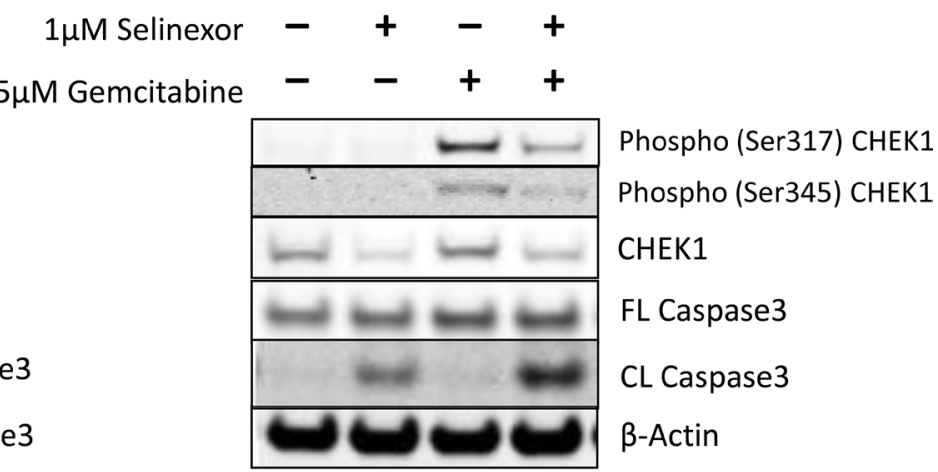

Pancreatic cancer cells Mia-PaCa

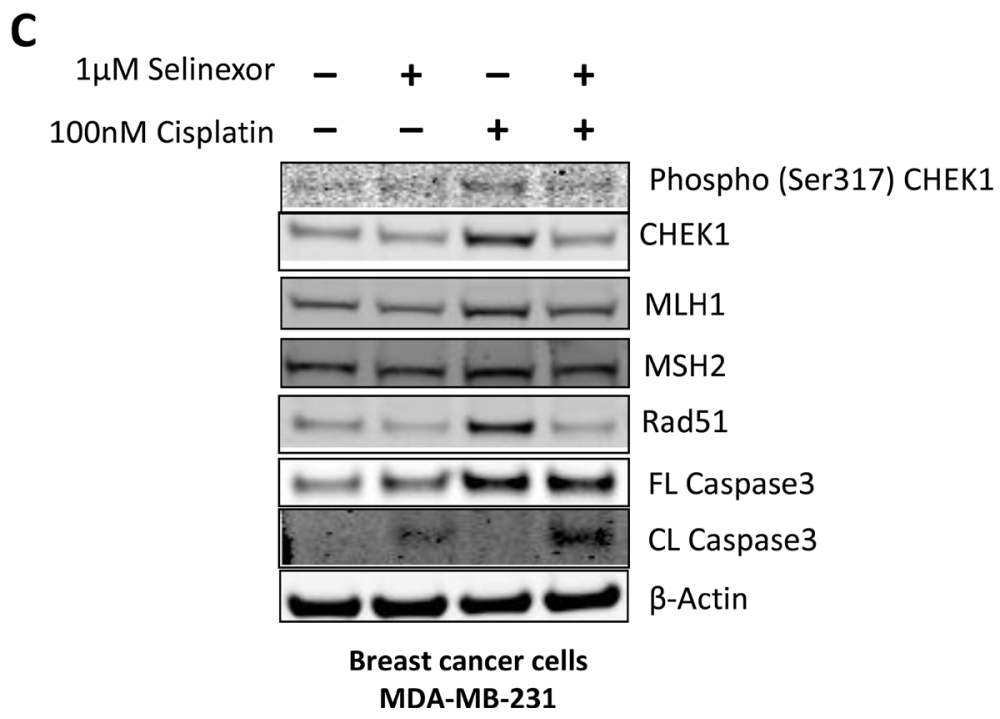

Figure 5: Selinexor exhibits synergistic cytotoxic effects in combination with chemotherapeutic agents. Immunoblots of whole cell lysates from MDA-MB-231 cells that were treated with (A) $1 \mu \mathrm{M}$ docetaxel or (C) $100 \mathrm{nM}$ cisplatin with or without $1 \mu \mathrm{M}$ selinexor for 24 hours or (B) MiaPaCa-2 cells that were treated with either $5 \mu \mathrm{M}$ gemcitabine, $1 \mu \mathrm{M}$ selinexor or the combination for 24 hours. Selinexor inhibited the expression of the DDR proteins CHEK1, MLH1, MSH2 and Rad51 upon exposure to the DDAs and resulted in synergistic cell killing. 
genes and sensitized cancer cells to different chemotherapies in vitro and in vivo. Importantly, this effect of selinexor on DDR gene product expression is a general phenomenon, not restricted to certain cancer types. Altogether, we show here that selinexor reduced the expression of gene products in five different DNA damage detection and repair mechanisms: (1) DNA damage sensory proteins (ATM, ATR, CHEK1 and Chk2), (2) homologous recombination $(\operatorname{Rad} 51$ [31], CHEK1 [17], BRCA1 and BRCA2 [32], Rad52 [33], FANCB [34], PALB2 [35]), (3) mismatch repair (MSH2, MSH6, MLH1, [36]), (4) nucleotide excision repair (ERCC1
[37], ERCC6 [38], RPA2 [39]), and (5) base excision repair (PARP1 [40], XRCC1 and DNA ligase 3 [41]). In addition, selinexor also reduced the expression of the master regulator of DNA damage repair FOXM1, which has roles in the repair mechanism in DNA damage recognition, remodeling, unwinding of chromatin, and excision of damaged DNA [42]. Seven of the gene products (Rad51, CHEK1, MLH1, MSH2, MSH6, PMS2 and PARP1) disrupted by selinexor were the focus of the study and their reduction at the protein level were confirmed. We showed that selinexor inhibited the expression of these genes in a dose-dependent manner in both solid and

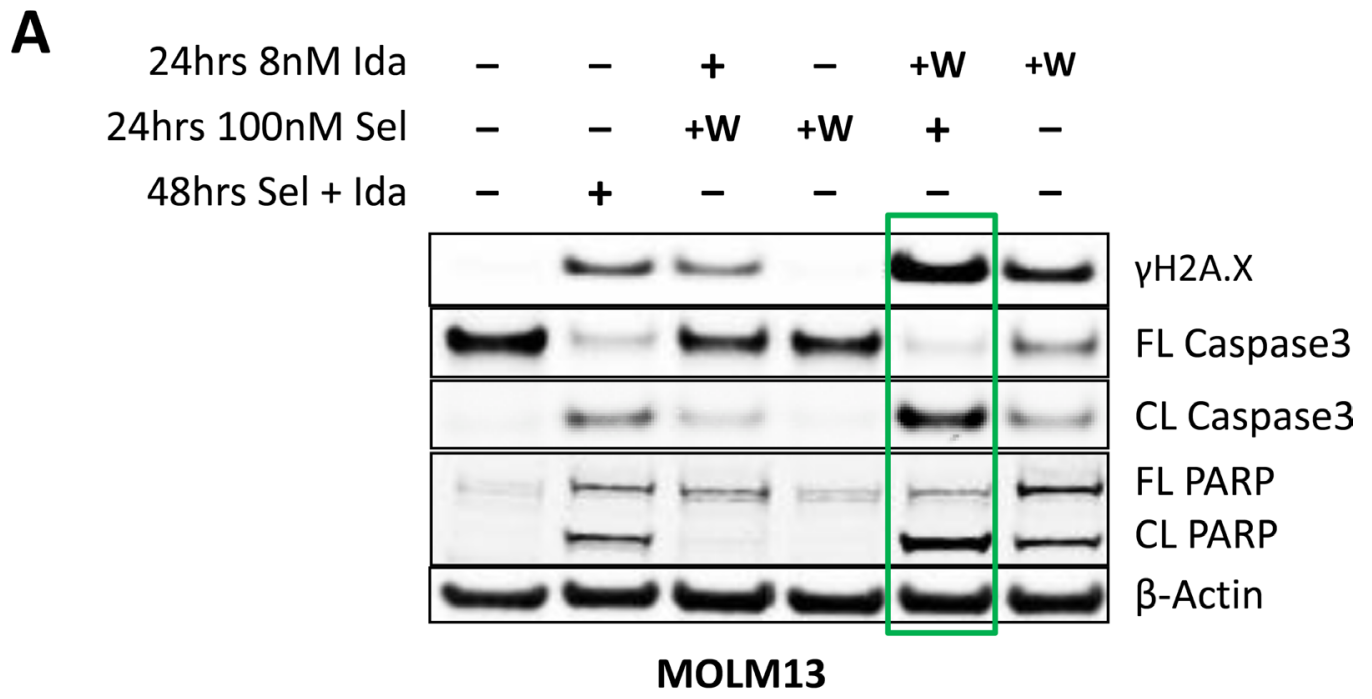

B

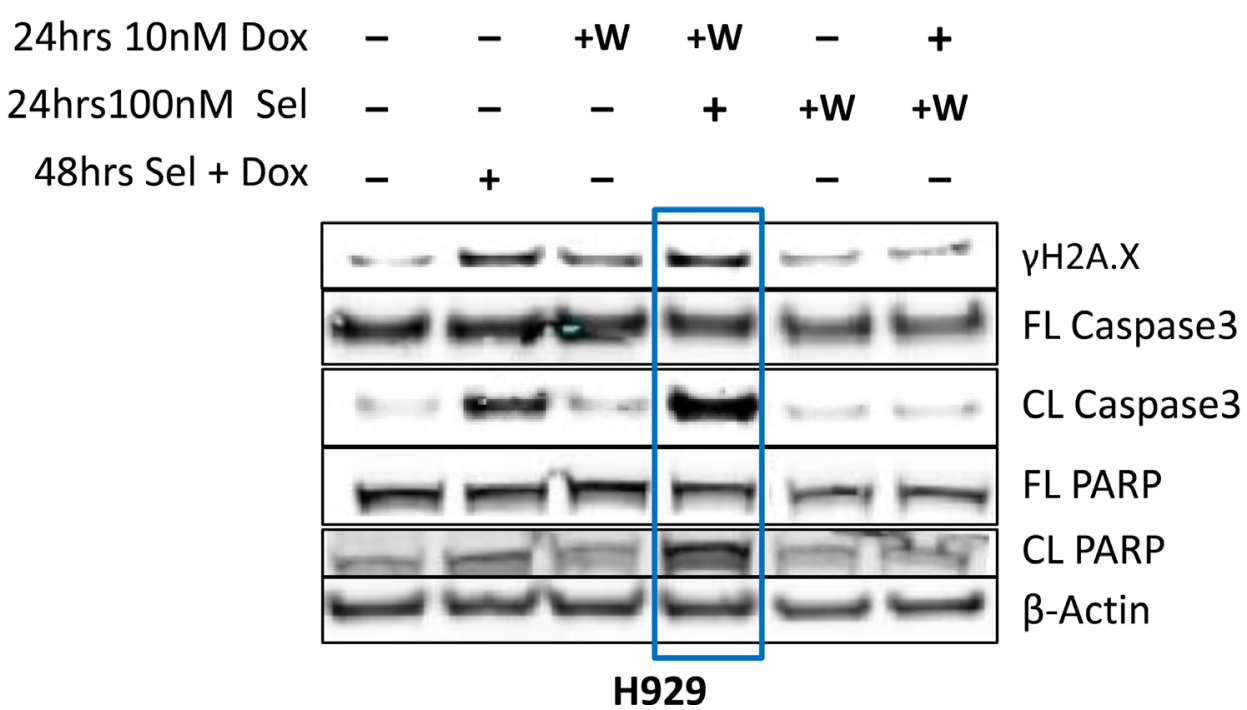

Figure 6: Pre-treatment with DDA followed by selinexor treatment is more cytotoxic than concomitant dosing or pretreatment with selinexor. (A) Immunoblot analysis of MOLM-13 cells that were either untreated or treated with idarubicin and (B) H929 cells that were either untreated or treated with doxorubicin for 24 hours (indicated by “+”), followed by a washout and subsequent treatment with selinexor. The sequence of treatment was then reversed such that cells were first treated with selinexor for 24 hours, washed and then treated with idarubicin or doxorubicin for additional 24 hours. The cells were also treated with each combination together for 48 hours as a control. Pre-treatment of MOLM-13 cells with idarubicin (green box) or H929 (blue box) cells with doxorubicin followed by exposure to selinexor induced more DNA damage and cell death than pre-treatment with selinexor followed by idarubicin or dexorubicin. 
hematological cancer cell lines. The inhibition is observed at the transcriptional level with the exception of PMS2 which was shown at the translational level only. Importantly, the inhibition of the DDR gene products is independent from cell death, as it is seen as early as 2 hours following selinexor treatment and much earlier than the 12-hour time point when cancer cell death is significant.

Visualization of the $\gamma \mathrm{H} 2 \mathrm{~A}$.X marker was used to detect DNA damage following treatment with DDAs and to examine if selinexor could directly damage the genome. H2A.X, a member of the H2A family of histones, is phosphorylated following a DSB [43] and is frequently used to indicate the presence of genomic insult. The results show that selinexor as a single-agent did not induce the $\gamma \mathrm{H} 2 \mathrm{~A}$.X modification and thus did not directly induce significant DNA damage. It was further demonstrated that when cancer cells were allowed to recover from DNA damage, $\gamma \mathrm{H} 2 \mathrm{~A}$.X foci return quickly to their basal levels, indicating recovery from genomic insult. However, when cells were exposed to a DDA and then treated with selinexor, $\gamma \mathrm{H} 2 \mathrm{~A} . \mathrm{X}$ foci persisted (up to 48 hours) after the withdrawal of the DSB inducing agent, indicating a delay in the repair process. While $\gamma \mathrm{H} 2 \mathrm{~A} . \mathrm{X}$ modifications occur in response to direct DSBs, they are also the end result of adducts, single strand breaks, replication or transcriptional blocking lesions [43]. This justifies using $\gamma \mathrm{H} 2 \mathrm{~A} . \mathrm{X}$ as a marker while studying cancer chemotherapies that induce different types of DNA damage [43]. These results suggest that the selinexor-related reduction of DDR proteins slowed or blocked the repair process. This is consistent with a previous study that we have performed highlighting the inhibitory effects of selinexor on homologous recombination [30].

Having shown that selinexor could impair or prolong the DDR process, we examined if the selinexorrelated delay in repair was observed in the presence of other chemotherapeutic agents and if this delay affected cell viability. The results showed enhanced cytotoxicity and increased apoptosis when selinexor was administered separately and as a follow-up treatment to the DDA. Primary treatment with selinexor followed by treatment with a DDA resulted in lower levels of cytotoxicity. This may have occurred because selinexor inhibits cell cycle progression and induces cell cycle arrest. As a result, cells
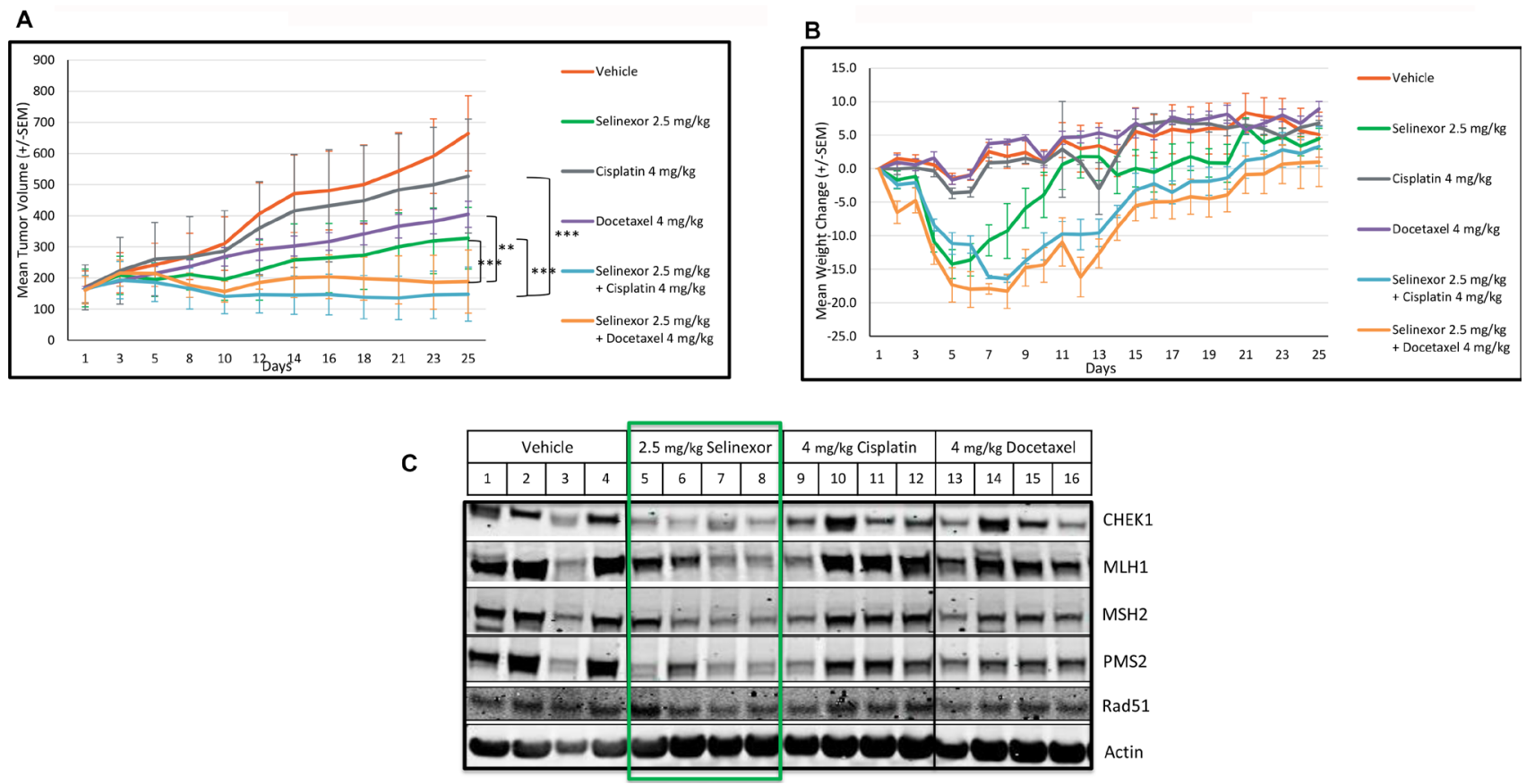

Figure 7: Selinexor demonstrates synergistic anti-tumor effects in combination with cisplatin or docetaxel and inhibits the expression of DDR proteins in an in vivo breast cancer model. $\mathrm{Nu} / \mathrm{nu}$ mice were allocated to six groups of 4 mice and treated with vehicle (1), $2.5 \mathrm{mg} / \mathrm{kg}$ selinexor (2), $4 \mathrm{mg} / \mathrm{kg}$ cisplatin (3), $4 \mathrm{mg} / \mathrm{kg}$ docetaxel (4), selinexor in combination with cisplatin (5) or docetaxel (6) for 25 days. For groups V and Vi, selinexor was administered 6 hours after treatment with cisplatin and docetaxel respectively. Selinexor was administered orally, whereas cisplatin and docetaxel were administered by intraperitoneal injection. (A) Mean tumor volumes were calculated from the length and width measurements. Group means were calculated and are shown with error bars representing standard error of the mean (SEM) for each group. Combinatory treatments inhibited tumor growth better than each single agent. (B) The percent daily weight changes for each animal and the means for each treatment group were calculated. Error bars represent the SEM. There was no significant weight change among the groups at the end of the study. (C) At the end of the in vivo xenograft study (day 25), excised tumors from the vehicle, selinexor, cisplatin and docetaxel treated groups were assayed either by immunoblots for the expression of DDR proteins. Selinexor, but not cisplatin or docetaxel, reduced the levels of DDR proteins: CHEK1, MLH1, MSH2, PMS2, $\operatorname{Rad} 51$. 
Table 1: Selinexor inhibits the steady state levels of gene products that regulate DNA damage repar of different mechanisms

\begin{tabular}{|c|c|c|c|}
\hline & Type of damage & Repair & Indication \\
\hline Cisplatin & $\begin{array}{l}\text { Alkylating agent cross links } \\
\text { and induces bulky lesions }\end{array}$ & $\begin{array}{l}\text { Nucleotide excision repair \& } \\
\text { Homologous recombination }\end{array}$ & $\begin{array}{l}\text { Carcinomas, sarcomas, } \\
\text { lymphomas, bladder cancer, } \\
\text { cervical cancer and germ cell } \\
\text { tumors }[21]\end{array}$ \\
\hline Gemcitabine & $\begin{array}{c}\text { Antimetabolite incorporates } \\
\text { into DNA }\end{array}$ & Homologous recombination & $\begin{array}{c}\text { Pancreatic, breast, ovarian, } \\
\text { bladder and non-small cell lung } \\
\text { cancer [22] }\end{array}$ \\
\hline $\begin{array}{l}\text { Doxorubicin \& } \\
\text { Idarubicin }\end{array}$ & $\begin{array}{l}\text { Anthracyclines inhibit topo } \\
\text { II and inhibit transcription, } \\
\text { resulting in DSBs }\end{array}$ & $\begin{array}{l}\text { Homologues recombination and } \\
\text { non-homologous end joining }\end{array}$ & $\begin{array}{c}\text { Leukemias, lymphomas, breast, } \\
\text { stomach, uterine, ovarian, } \\
\text { bladder and lung cancer [23] }\end{array}$ \\
\hline Docetaxel & $\begin{array}{l}\text { Inhibits microtubule } \\
\text { dynamics, which disrupts } \\
\text { DDR protein trafficking } \\
\text { resulting in SSB }\end{array}$ & $\begin{array}{l}\text { Base Excision Repair and } \\
\text { Mismatch Repair }\end{array}$ & $\begin{array}{l}\text { Breast, head and, stomach, } \\
\text { prostate and non-small cell lung } \\
\text { cancer [24] }\end{array}$ \\
\hline
\end{tabular}

HT1080 fibrosarcoma cells were treated with 0 (control), 100 or $1000 \mathrm{nM}$ selinexor for 24 hours. Real-Time PCR gene expression assay demonstrates that selinexor inhibits DNA repair protein gene expression of several functional groups: Checkpoint (early response), recombination repair, base excision repair, nucleotide excision repair, and mismatch DNA repair mechanism.

do not enter into S-phase and initiate DNA replication and are thus less sensitive to chemotherapeutic agents. Therefore, in order to achieve maximal cytotoxicity, DNA damage should be induced prior to the administration of selinexor.

The results and conclusions described here reveal a mechanistic explanation for previous observations that show selinexor enhances the in vitro and in vivo effects of DNA damage inducing therapies: (1) doxorubicin in multiple myeloma [44], (2) platinum-based chemotherapies in ovarian cancer [45], (3) nucleoside analogues in leukemia and pancreatic cancers [46, 47], and (4) radiation therapy in rectal cancer [48], and (5) unpublished data in non-small cell lung cancer. Radiation therapy, like chemotherapy, can induce many types of DNA damage, including simple lesions, such as base or sugar modifications, DNA crosslinks, single-strand breaks and more complex lesions, such as DNA double-strand breaks [12]. Using rectal cancer models, Ferreiro-Neira et al. showed that radiotherapy in combination with selinexor increased apoptosis and decreased the rate of proliferation, when compared to radiotherapy alone, both in vivo and in vitro [48]. These data suggest that selinexor synergizes with radiation therapy using similar mechanism of DDR inhibition as demonstrated for combination with chemotherapy.

Cancers are heterogeneous diseases which may carry mutations or epigenetic defects that result in elevated activity or deficiencies in DDR pathways. Microsatellite instability, for example, could potentially be used as a marker to identify repair deficiencies and help select the best type of DNA damage repair agent to combine with selinexor when a defect in mismatch repair is identified [36]. Therefore, gaining patientspecific genetic information on DDR genes should aid in the selection of the optimal combination treatment. In the same way, BRCA1/2 deficient tumors have HR DNA repair deficiency; however, in a subset of these tumors, overexpression of the DNA repair protein FANCD2 helps maintain DDR and repair by relying on NHEJ instead of HR [49]. This information could be exploited by inducing DNA damage and inhibiting the DDR with the addition of selinexor. Understanding the genomic background of the tumor will enable treating physicians to customize a combination regimen targeting specific DDR deficiencies. While these preclinical studies strongly suggest an enhanced benefit from the combination treatment of selinexor with DNA damage inducing therapy, future studies should focus on matching a specific DNA damage inducing therapy with selinexor to a specific tumor type harboring mutations in DDR genes with the goal of achieving maximal therapeutic benefit. Moreover, DDAs are not selective for cancer cells and have side effects at therapeutic doses [50]. Adverse effects are also reported in patients treated with selinexor (e.g. weight loss) [6, 8]. The in vivo studies showed that combination treatment of low-dose selinexor and low-dose chemotherapeutic agents were synergistic with limited effects on weight loss suggesting that combination treatments may enable efficacy at lower doses and improve tolerability.

In conclusion, the findings presented in this study suggest that the sequential treatment of DNA damage inducing chemotherapeutic agents followed by selinexor results in therapeutic synergy. The combination of these drugs is expected to allow administration of lower doses of 
each agent, which could mitigate adverse effects of cancer patients in need of effective treatment.

\section{MATERIALS AND METHODS}

\section{Cell lines and primary samples}

MM.1S (\#CRL-2974), H929 (\#CRL-9068), Toledo (\#CRL-2631)，THP-1 (TIB-202), A549 (CCL-185), HT1080 (\#CCL-121), U-2 OS (\#HTB-96), MiaPaCa-2 (\#CRL-1420), MDA-MB-231 (HTB-26) were purchased from ATCC (Manassas, VA, USA), MOLM13 cells (\#ACC554) were purchased from DSMZ (Braunschweig, Germany) and ASPS-KY (Hoshino et al. 2009) were obtained with the permission of Dr. Shunsuke Yanoma. MM.1S, H929, Toledo, THP-1, ASPS-KY and MDAMB-231 cells were cultured in RPMI-1640 medium (\#10040-CV; Corning). A549 cells were cultured in F12-K medium (\#21127-022; Gibco). MiaPaCa-2 cells were cultured in Dulbecco's Modified Eagle's medium (\#10013-CV; Corning). HT1080 cells were cultured in Eagle's Minimum Essential medium (\#10-010-CV; Corning). U-2 OS cells were cultured in McCoy's 5A medium (\#12330031; Gibco). Cell media was supplemented with $10 \%$ fetal bovine serum, penicillin $10,000 \mathrm{U} / \mathrm{mL}$, and streptomycin 10,000 $\mu \mathrm{g} / \mathrm{mL}$ (\#15140-122; Gibco).

\section{Compounds}

Selinexor was obtained from Karyopharm Therapeutics. Docetaxel (\#S1148), cisplatin (\#S1166), idarubicin (\#S1228), gemcitabine (\#S1714), and doxorubicin (\#S1208) were purchased from Selleckchem (Houston, TX, USA).

\section{Taqman gene assays and antibodies}

Real-time PCR Taqman gene probes were purchased from Life Technologies (Carlsbad, CA, USA) (MSH2: Hs00953523 m1; MLH1: Hs00179866 m1; MSH6: Hs00264721_m1; PMS2: HS00241053_m1; Rad51: Hs00153418_m1; CHEK1: Hs00967506_m1). The antibodies for PARP-1 (\#9542), Caspase-3 (\#9662), Rad51 (\#8875), MLH1 (\#3515), CHEK1 (\#2360), Gamma H2A.X (\#9718), MSH2 (\#2850) were purchased from Cell Signaling (Danvers, MA, USA); PMS2 (\#2251.00.02) and MSH6 (\#2203.00.02) antibodies were purchased from Sdix (Newark, DE, USA). Antibodies targeting XPO1 (\#sc-5595) and beta-actin (\#sc-81178) were purchased from Santa Cruz Biotechnology. The secondary antibodies for western blotting were purchased form LI-COR (Lincoln, NE, USA) and the secondary antibodies for immunofluorescence were purchased from Life Technologies (\#A11008).

\section{Real-time quantitative reverse transcription- PCR}

RNA was extracted from cells using the RNeasy Kit (\#74106, Qiagen) and reverse transcribed to cDNA using High Capacity cDNA Reverse Transcription Kit (\#4368813, Applied Biosystems). mRNA for the indicated genes was quantified using a ViiA7 Real-Time PCR system and analyzed with V1.2 software (Life Technologies).

\section{Western blotting}

Cells were seeded in 6 well plates at a density of $1.5 \times 10^{6}$ (hematological cells) or $0.5 \times 10^{6}$ (solid cells), treated according to the experimental setup, washed with 1X PBS and then lysed with RIPA buffer (\#89901, Thermo Scientific) supplemented with protease inhibitors (\# 05892791001, Roche) and phosphatase inhibitors (\# 04906837001, Roche). Protein levels were quantified using BCA (\#23225, Thermo Scientific). $20 \mu \mathrm{g}$ of each sample was run in 4-12\% Bis-Tris Gel (Life Technologies) and later transferred to nitrocellulose membrane using iBlot Gel Transfer Kit (Life Technologies). The membranes were blocked using LI-COR blocking buffer (\#927-40000, LI-COR), probed with the indicated antibodies, and analyzed using LI-COR Odyssey.

\section{DNA damage recovery assay}

U-2 OS cells were seeded in 6-well plates at a density of $0.5 \times 10^{6}$ cells/well and allowed to adhere to collagen treated coverslips overnight. The following day, the cells were treated for 2 hours with $0.5 \mu \mathrm{g} / \mathrm{mL}$ doxorubicin. The media was then removed and replaced by media containing DMSO or $1 \mu \mathrm{M}$ selinexor for 48 hours. The cells were fixed using ice-cold $100 \%$ methanol for 15 minutes, washed with $1 \mathrm{X}$ PBS, and then blocked/permeabilized using a solution containing $0.1 \%$ Tween-20, $0.3 \mathrm{M}$ Glycine, and $1 \%$ BSA in $1 X$ PBS. The cells were incubated with the gamma H2A.X $(\gamma \mathrm{H} 2 \mathrm{~A} . \mathrm{X})$ antibody overnight at $4^{\circ} \mathrm{C}$, and then washed 3 times with $1 \mathrm{X}$ PBS before incubation with secondary antibody $(1: 2000)$ for 1 hour. The cells were washed with $1 \mathrm{X}$ PBS, and counterstained with DAPI for 5 minutes and then mounted to a glass slide using Vectashield mounting medium (\#H-1400, Vector Laboratories). The coverslips were allowed to dry on the glass slide for a minimum of 4 hours before analysis with a fluorescent microscope.

\section{Sequential/concomitant combination study}

MOLM-13 and H929 cells were first treated with $8 \mathrm{nM}$ idarubicin and $10 \mathrm{nM}$ doxorubicin respectively for 24 hours, followed by treatment with $100 \mathrm{nM}$ selinexor for the next 24 hours. In addition, the order of treatments was reversed (selinexor followed by exposure to idarubicin or 
Table 2: Xenograft study design

\begin{tabular}{lccccc}
\hline Group & $\begin{array}{c}\text { Number of } \\
\text { animals }\end{array}$ & Test article & Dose & $\begin{array}{c}\text { Route of } \\
\text { administration }\end{array}$ & Schedule \\
\hline $\mathbf{1}$ & 4 & $\begin{array}{c}\text { Vehicle (0.6\%Pluronic F-68 } \\
\text { and 0.6\%PVP K29/32) }\end{array}$ & $0.1 \mathrm{ml} / 10 \mathrm{~g}$ & PO & MWF \\
$\mathbf{2}$ & 4 & Selinexor & $2.5 \mathrm{mg} / \mathrm{kg}$ & PO & MWF \\
$\mathbf{3}$ & 4 & Cisplatin & $4 \mathrm{mg} / \mathrm{kg}$ & IP & Q7D \\
$\mathbf{4}$ & 4 & Docetaxel & $4 \mathrm{mg} / \mathrm{kg}$ & IP & Q7D \\
$\mathbf{5}$ & 4 & Cisplatin & $4 \mathrm{mg} / \mathrm{kg}$ & IP & Q7D \\
& & Selinexor & $2.5 \mathrm{mg} / \mathrm{kg}$ & PO & MWF \\
$\mathbf{6}$ & 4 & Docetaxel & $4 \mathrm{mg} / \mathrm{kg}$ & IP & Q7D \\
\hline
\end{tabular}

$24 \mathrm{nu} / \mathrm{nu}$ mice were allocated to six groups of four mice such that the mean tumor volume in each group was within the range of 161-172 $\mathrm{mm}^{3}$. Mice were treated with vehicle, selinexor, cisplatin and docetaxel. Abbreviations: PO, oral; IP, intraperitoneal; MWF, Monday, Wednesday and Friday; Q7D, daily for 7 days.

doxorubicin). As experimental controls, MOLM13 cells were treated with combination of selinexor and idarubicin and H929 cells were treated with combination of selinexor and doxorubicin, for $48 \mathrm{hrs}$. The cells were harvested and subjected to SDS-PAGE and immunoblot analysis for gamma H2A.X, caspase-3, PARP-1 and beta-actin.

\section{Immunohistochemistry}

Formalin-fixed paraffin-embedded (FFPE) tissue blocks were sectioned at $4 \mu \mathrm{m}$, and deparaffinized through three washes in xylene and a decreasing series of ethanol. Antigen retrieval was performed in a steam cooker for 15 minutes in Declere (Cell Marque) working solution. Endogenous hydrogenase was blocked with 3\% hydrogen peroxide for five minutes. Slides were incubated in casein-based protein block (Biogenex) for 20 minutes before incubation with the respective antibodies at room temperature for 30 minutes. Slides were then rinsed with buffer and incubated with Amplifier from Hi-Def Polymer Detection Kit (Cell Marque) for 10 minutes at room temperature. Afterwards slides were rinsed with buffer and incubated in DAB chromogen for six minutes at room temperature for color development. The slides were counterstained with Hematoxylin I (Richard Allan Scientific), rinsed in water, and dehydrated through a series of increasing ethanol and three changes of xylene. Slides were mounted on coverslips. Digital images of slides were generated via Aperio AT scanner at 20×. Immunohistochemistry assays were performed on a Biogenex i6000 automated stainer. Masson's Trichrome (Polyscientific) staining was performed manually as per the manufacturer's instructions.

\section{Xenograft study}

Twenty-four nude mice (Taconic Biosciences), aged 7 to 8 weeks were inoculated subcutaneously with $2 \times 10^{7}$
MDA-MB-231 (ATCC \# HTB-26) breast adenocarcinoma cells. The mean body weight prior to treatment was $21.9 \mathrm{~g}$ (standard deviation $\pm 1.7 \mathrm{~g}(\mathrm{CV}=7.7 \%)$, range 19.1-24.8 g). Treatment was initiated when the tumors reached a mean volume of $167 \mathrm{~mm}^{3}$ (standard deviation $\pm 89.8 \mathrm{~mm}^{3}$, $(\mathrm{CV}=54 \%)$, range $\left.50-365 \mathrm{~mm}^{3}\right)$. Mice were allocated to six groups of four mice such that the mean tumor volume in each group was within the range of $161-172 \mathrm{~mm}^{3}$. Mice were treated with vehicle, selinexor, cisplatin, and/ or docetaxel as shown in Table 2. For the combination group, 5 and 6, treatment with selinexor followed 6 hours post dosing with the DDAs. Animal weights and condition were recorded daily. Tumors were measured once every two days with micro-calipers, and tumor volume was calculated as (length $\times$ width $\times$ width) $/ 2$. Statistical differences between treatment groups were determined using Mann-Whitney Rank Sum or ANOVA tests with a critical value of $p<0.05$.

\section{ACKNOWLEDGMENTS}

We would like to thank John Pugliese for providing significant inspiration.

\section{CONFLICTS OF INTEREST}

The authors from Karyopharm Therapeutics are all full time Karyopharm employees and have no conflicts of interest to disclose. All authors have read and approved the manuscript for publication in "Oncotarget".

\section{REFERENCES}

1. El-Tanani M, Dakir H, Raynor B, Morgan R. Mechanisms of Nuclear Export in Cancer and Resistance to Chemotherapy. Cancers (Basel). 2016; 8:8. https://doi.org/10.3390/ cancers 8030035 . 
2. Huang WY, Yue L, Qiu WS, Wang LW, Zhou XH, Sun YJ. Prognostic value of CRM1 in pancreas cancer. Clin Invest Med. 2009; 32:E315. https://doi.org/10.25011/cim. v32i6.10668.

3. Noske A, Weichert W, Niesporek S, Röske A, Buckendahl AC, Koch I, Sehouli J, Dietel M, Denkert C. Expression of the nuclear export protein chromosomal region maintenance/exportin $1 / \mathrm{Xpo} 1$ is a prognostic factor in human ovarian cancer. Cancer. 2008; 112:1733-43. https:// doi.org/10.1002/cncr.23354.

4. Schmidt J, Braggio E, Kortuem KM, Egan JB, Zhu YX, Xin CS, Tiedemann RE, Palmer SE, Garbitt VM, McCauley D, Kauffman M, Shacham S, Chesi M, et al. Genome-wide studies in multiple myeloma identify XPO1/CRM1 as a critical target validated using the selective nuclear export inhibitor KPT-276. Leukemia. 2013; 27:2357-65. https:// doi.org/10.1038/leu.2013.172.

5. Yao Y, Dong Y, Lin F, Zhao H, Shen Z, Chen P, Sun YJ, Tang LN, Zheng SE. The expression of CRM1 is associated with prognosis in human osteosarcoma. Oncol Rep. 2009; 21:229-35.

6. Abdul Razak AR, Mau-Soerensen M, Gabrail NY, Gerecitano JF, Shields AF, Unger TJ, Saint-Martin JR, Carlson R, Landesman Y, McCauley D, Rashal T, Lassen U, Kim R, et al. First-in-Class, First-in-Human Phase I Study of Selinexor, a Selective Inhibitor of Nuclear Export, in Patients With Advanced Solid Tumors. J Clin Oncol. 2016; 34:4142-50. https://doi.org/10.1200/JCO.2015.65.3949.

7. Lassen UN, Mau-Soerensen M, Kung AL, Wen PY, Lee EQ, Plotkin SR, Muhic A, Rashal T, Williams T, McCauley D, Ellis J, Saint-Martin JR, Carlson R, et al. A phase 2 study on efficacy, safety and intratumoral pharmacokinetics of oral selinexor (KPT-330) in patients with recurrent glioblastoma (GBM). J Clin Oncol. 2015; 33:2044.

8. Gounder MM, Zer A, Tap WD, Salah S, Dickson MA, Gupta AA, Keohan ML, Loong HH, D’Angelo SP, Baker S, Condy M, Nyquist-Schultz K, Tanner L, et al. Phase IB Study of Selinexor, a First-in-Class Inhibitor of Nuclear Export, in Patients With Advanced Refractory Bone or Soft Tissue Sarcoma. J Clin Oncol. 2016; 34:3166-74. https:// doi.org/10.1200/JCO.2016.67.6346.

9. Senapedis WT, Baloglu E, Landesman Y. Clinical translation of nuclear export inhibitors in cancer. Semin Cancer Biol. 2014; 27:74-86. https://doi.org/10.1016/j. semcancer.2014.04.005.

10. Branzei D, Foiani M. Regulation of DNA repair throughout the cell cycle. Nat Rev Mol Cell Biol. 2008; 9:297-308. https://doi.org/10.1038/nrm2351.

11. Altieri F, Grillo C, Maceroni M, Chichiarelli S. DNA damage and repair: from molecular mechanisms to health implications. Antioxid Redox Signal. 2008; 10:891-937. https://doi.org/10.1089/ars.2007.1830.

12. Pearl LH, Schierz AC, Ward SE, Al-Lazikani B, Pearl FM. Therapeutic opportunities within the DNA damage response. Nat Rev Cancer. 2015; 15:166-80. https://doi. org/10.1038/nrc3891.

13. Bouwman P, Jonkers J. The effects of deregulated DNA damage signalling on cancer chemotherapy response and resistance. Nat Rev Cancer. 2012; 12:587-98. https://doi. org/10.1038/nrc3342.

14. Curtin NJ. Inhibiting the DNA damage response as a therapeutic manoeuvre in cancer. Br J Pharmacol. 2013; 169:1745-65. https://doi.org/10.1111/bph.12244.

15. Yuan $Y$, Hong $X$, Lin ZT, Wang $H$, Heon $M$, Wu $T$. Protein Arrays III: Reverse-Phase Protein Arrays. Methods Mol Biol. 2017; 1654:279-89. https://doi. org/10.1007/978-1-4939-7231-9_21.

16. Krämer A, Green J, Pollard J Jr, Tugendreich S. Causal analysis approaches in Ingenuity Pathway Analysis. Bioinformatics. 2014; 30:523-30. https://doi.org/10.1093/ bioinformatics/btt703.

17. Zhao H, Piwnica-Worms H. ATR-mediated checkpoint pathways regulate phosphorylation and activation of human Chk1. Mol Cell Biol. 2001; 21:4129-39. https://doi. org/10.1128/MCB.21.13.4129-4139.2001.

18. Volpon L, Culjkovic-Kraljacic B, Sohn HS, Blanchet-Cohen A, Osborne MJ, Borden KL. A biochemical framework for eIF4E-dependent mRNA export and nuclear recycling of the export machinery. RNA. 2017; 23:927-37. https://doi. org/10.1261/rna.060137.116.

19. Lin CJ, Malina A, Pelletier J. c-Myc and eIF4F constitute a feedforward loop that regulates cell growth: implications for anticancer therapy. Cancer Res. 2009; 69:7491-94. https://doi.org/10.1158/0008-5472.CAN-09-0813.

20. Tian H, Gao Z, Li H, Zhang B, Wang G, Zhang Q, Pei D, Zheng J. DNA damage response - a double-edged sword in cancer prevention and cancer therapy. Cancer Lett. 2015; 358:8-16. https://doi.org/10.1016/j.canlet.2014.12.038.

21. Eastman A. Activation of programmed cell death by anticancer agents: cisplatin as a model system. Cancer Cells. 1990; 2:275-80..

22. Ewald B, Sampath D, Plunkett W. Nucleoside analogs: molecular mechanisms signaling cell death. Oncogene. 2008; 27:6522-37. https://doi.org/10.1038/onc.2008.316.

23. Thorn CF, Oshiro C, Marsh S, Hernandez-Boussard T, McLeod H, Klein TE, Altman RB. Doxorubicin pathways: pharmacodynamics and adverse effects. Pharmacogenet Genomics. 2011; 21:440-46. https://doi.org/10.1097/ FPC.0b013e32833ffb56.

24. Montero A, Fossella F, Hortobagyi G, Valero V. Docetaxel for treatment of solid tumours: a systematic review of clinical data. Lancet Oncol. 2005; 6:229-39. https://doi. org/10.1016/S1470-2045(05)70094-2.

25. Tai YT, Landesman Y, Acharya C, Calle Y, Zhong MY, Cea M, Tannenbaum D, Cagnetta A, Reagan M, Munshi AA, Senapedis W, Saint-Martin JR, Kashyap T, et al. CRM1 inhibition induces tumor cell cytotoxicity and impairs osteoclastogenesis in multiple myeloma: molecular 
mechanisms and therapeutic implications. Leukemia. 2014; 28:155-65. https://doi.org/10.1038/leu.2013.115.

26. Tabe Y, Kojima K, Yamamoto S, Sekihara K, Matsushita H, Davis RE, Wang Z, Ma W, Ishizawa J, Kazuno S, Kauffman M, Shacham S, Fujimura T, et al. Ribosomal Biogenesis and Translational Flux Inhibition by the Selective Inhibitor of Nuclear Export (SINE) XPO1 Antagonist KPT-185. PLoS One. 2015; 10:e0137210. https://doi.org/10.1371/journal. pone. 0137210 .

27. Zhong Y, El-Gamal D, Dubovsky JA, Beckwith KA, Harrington BK, Williams KE, Goettl VM, Jha S, Mo X, Jones JA, Flynn JM, Maddocks KJ, Andritsos LA, et al. Selinexor suppresses downstream effectors of B-cell activation, proliferation and migration in chronic lymphocytic leukemia cells. Leukemia. 2014; 28:1158-63. https://doi.org/10.1038/leu.2014.9.

28. Sun H, Hattori N, Chien W, Sun Q, Sudo M, E-Ling GL, Ding L, Lim SL, Shacham S, Kauffman M, Nakamaki T, Koeffler HP. KPT-330 has antitumour activity against nonsmall cell lung cancer. Br J Cancer. 2014; 111:281-91. https://doi.org/10.1038/bjc.2014.260.

29. Lin DC, Hao JJ, Nagata Y, Xu L, Shang L, Meng X, Sato Y, Okuno Y, Varela AM, Ding LW, Garg M, Liu LZ, Yang H, et al. Genomic and molecular characterization of esophageal squamous cell carcinoma. Nat Genet. 2014; 46:467-73. https://doi.org/10.1038/ng.2935.

30. Ranganathan P, Kashyap T, Yu X, Meng X, Lai TH, McNeil B, Bhatnagar B, Shacham S, Kauffman M, Dorrance AM, Blum W, Sampath D, Landesman Y, Garzon R. XPO1 Inhibition using Selinexor Synergizes with Chemotherapy in Acute Myeloid Leukemia by Targeting DNA Repair and Restoring Topoisomerase II $\alpha$ to the Nucleus. Clin Cancer Res. 2016; 22:6142-52. https://doi.org/10.1158/1078-0432. CCR-15-2885.

31. Nagathihalli NS, Nagaraju G. RAD51 as a potential biomarker and therapeutic target for pancreatic cancer. Biochim Biophys Acta. 2011; 1816:209-18.

32. Tutt A, Ashworth A. The relationship between the roles of BRCA genes in DNA repair and cancer predisposition. Trends Mol Med. 2002; 8:571-76. https://doi.org/10.1016/ S1471-4914(02)02434-6.

33. Hanamshet K, Mazina OM, Mazin AV. Reappearance from Obscurity: Mammalian Rad52 in Homologous Recombination. Genes (Basel). 2016; 7:7. https://doi. org/10.3390/genes7090063.

34. Kim TM, Ko JH, Choi YJ, Hu L, Hasty P. The phenotype of FancB-mutant mouse embryonic stem cells. Mutat Res. 2011; 712:20-27. https://doi.org/10.1016/j.mrfmmm.2011.03.010.

35. Sy SM, Huen MS, Chen J. PALB2 is an integral component of the BRCA complex required for homologous recombination repair. Proc Natl Acad Sci U S A. 2009; 106:7155-60. https://doi.org/10.1073/pnas.0811159106.

36. Richman S. Deficient mismatch repair: read all about it (Review). Int J Oncol. 2015; 47:1189-202. https://doi. org/10.3892/ijo.2015.3119.
37. Smith DH, Fiehn AM, Fogh L, Christensen IJ, Hansen TP, Stenvang J, Nielsen HJ, Nielsen KV, Hasselby JP, Brünner $\mathrm{N}$, Jensen SS. Measuring ERCC1 protein expression in cancer specimens: validation of a novel antibody. Sci Rep. 2014; 4:4313. https://doi.org/10.1038/srep04313.

38. van Hoffen A, Natarajan AT, Mayne LV, van Zeeland AA, Mullenders LH, Venema J. Deficient repair of the transcribed strand of active genes in Cockayne's syndrome cells. Nucleic Acids Res. 1993; 21:5890-95. https://doi. org/10.1093/nar/21.25.5890.

39. Bastin-Shanower SA, Brill SJ. Functional analysis of the four DNA binding domains of replication protein $\mathrm{A}$. The role of RPA2 in ssDNA binding. J Biol Chem. 2001; 276:36446-53. https://doi.org/10.1074/jbc.M104386200.

40. Satoh MS, Lindahl T. Role of poly(ADP-ribose) formation in DNA repair. Nature. 1992; 356:356-58. https://doi. org/10.1038/356356a0.

41. Cappelli E, Taylor R, Cevasco M, Abbondandolo A, Caldecott K, Frosina G. Involvement of XRCC1 and DNA ligase III gene products in DNA base excision repair. J Biol Chem. 1997; 272:23970-75. https://doi.org/10.1074/ jbc.272.38.23970.

42. Zona S, Bella L, Burton MJ, Nestal de Moraes G, Lam EW. FOXM1: an emerging master regulator of DNA damage response and genotoxic agent resistance. Biochim Biophys Acta. 2014; 1839:1316-22. https://doi.org/10.1016/j. bbagrm.2014.09.016.

43. Sánchez-Flores M, Pásaro E, Bonassi S, Laffon B, Valdiglesias V. $\gamma \mathrm{H} 2 \mathrm{AX}$ assay as DNA damage biomarker for human population studies: defining experimental conditions. Toxicol Sci. 2015; 144:406-13. https://doi. org/10.1093/toxsci/kfv011.

44. Turner JG, Dawson J, Emmons MF, Cubitt CL, Kauffman M, Shacham S, Hazlehurst LA, Sullivan DM. CRM1 Inhibition Sensitizes Drug Resistant Human Myeloma Cells to Topoisomerase II and Proteasome Inhibitors both In Vitro and Ex Vivo. J Cancer. 2013; 4:614-25. https://doi. org/10.7150/jca.7080.

45. Chen Y, Camacho SC, Silvers TR, Razak AR, Gabrail NY, Gerecitano JF, Kalir E, Pereira E, Evans BR, Ramus SJ, Huang F, Priedigkeit N, Rodriguez E, et al. Inhibition of the Nuclear Export Receptor XPO1 as a Therapeutic Target for Platinum-Resistant Ovarian Cancer. Clin Cancer Res. 2017; 23:1552-63. https://doi.org/10.1158/1078-0432. CCR-16-1333.

46. Alexander TB, Lacayo NJ, Choi JK, Ribeiro RC, Pui CH, Rubnitz JE. Phase I Study of Selinexor, a Selective Inhibitor of Nuclear Export, in Combination With Fludarabine and Cytarabine, in Pediatric Relapsed or Refractory Acute Leukemia. J Clin Oncol. 2016; 34:4094-101. https://doi. org/10.1200/JCO.2016.67.5066.

47. Kazim S, Malafa MP, Coppola D, Husain K, Zibadi S, Kashyap T, Crochiere M, Landesman Y, Rashal T, Sullivan DM, Mahipal A. Selective Nuclear Export Inhibitor KPT330 Enhances the Antitumor Activity of Gemcitabine in 
Human Pancreatic Cancer. Mol Cancer Ther. 2015; 14:157081. https://doi.org/10.1158/1535-7163.MCT-15-0104.

48. Ferreiro-Neira I, Torres NE, Liesenfeld LF, Chan $\mathrm{CH}$, Penson T, Landesman Y, Senapedis W, Shacham S, Hong TS, Cusack JC. XPO1 Inhibition Enhances Radiation Response in Preclinical Models of Rectal Cancer. Clin Cancer Res. 2016; 22:1663-73. https://doi. org/10.1158/1078-0432.CCR-15-0978.

49. Kais Z, Rondinelli B, Holmes A, O'Leary C, Kozono D, D'Andrea AD, Ceccaldi R. FANCD2 Maintains Fork Stability in BRCA1/2-Deficient Tumors and Promotes
Alternative End-Joining DNA Repair. Cell Reports. 2016; 15:2488-99. https://doi.org/10.1016/j.celrep.2016.05.031.

50. Aoyagi T, Terracina KP, Raza A, Matsubara H, Takabe K. Cancer cachexia, mechanism and treatment. World J Gastrointest Oncol. 2015; 7:17-29. https://doi.org/10.4251/ wjgo.v7.i4.17. 